\title{
MEASURING CITIZEN SATISFACTION. PROSPECTS FOR USING A QUESTIONNAIRE TO MANAGE RELATIONSHIPS BETWEEN LOCAL GOVERNMENT AND CITIZENS IN THE CZECH REPUBLIC
}

\author{
[Měření spokojenosti občanů. Výhledy na použití dotazníku k řízení vztahu \\ mezi místní samosprávou a občany v České republice]
}

\author{
Kateřina Kantorová ${ }^{1}$, Tomáš Růžička ${ }^{2}$ \\ ${ }^{1}$ University of Pardubice, Faculty of Economics and Administration, Institute of Business Economics \\ and Management, Studentská 95, Pardubice 53210 \\ Email: katerina.kantorova@upce.cz. \\ ${ }^{2}$ University of Pardubice, Faculty of Economics and Administration, Institute of Business Economics \\ and Management, Studentská 95, Pardubice 53210 \\ Email: tomas.ruzicka01@gmail.com
}

\begin{abstract}
The authors of this text aimed to the possibility of determination of citizens' satisfaction with services provided by authorities at the municipal level in the Czech Republic. The analysis of current approaches used for the citizens' satisfaction determination was performed. Based on fund fact the authors proposed the application of methodology used by companies, modified for the municipality purposes. The application and the verification of methodologic proposal were performed in the town of Pardubice in the year 2014. The questionnaire research was used for data collection.
\end{abstract}

Keywords: local government, marketing, measuring citizen satisfaction, public sector.

JEL Classification: H40, M31, M54

Doručeno redakci: 30.6.2015; Recenzováno: 29.7.2015; 15.8.2015; Schváleno k publikování: 15.12.2015

\section{Introduction}

Currently, cities and regions are trying to acquire feedback from their citizens/clients and, with their help, establish more suitable conditions Maria (2013), increase quality, and thus maintain or improve citizen satisfaction. Mutual communication allows local authorities to become more effective, acquire support for strategic decisions, and engage citizens in public life, improving the region's competitiveness Fil'a et al. (2015); Rumpel (2011).

It can be seen from the research of Poister and Streib (1999), for example, that thousands of cities in the USA have already been participating in evaluating the performance of administrative bodies for several decades. It is also apparent that more than a third of municipalities in the USA with a population over 25,000 inhabitants use the results of these surveys as the foundation for their fiscal and political decisions. A research conducted in Slovakia shows that just under $60 \%$ of municipalities determine the satisfaction of their citizens using a survey and that town councilors are aware of the importance of such surveys even in municipalities where a survey has not yet been conducted Fil'a et al. (2015). In the nonprofit sphere, it is not only municipalities that use marketing tools in the form of a survey Freter (1989); Šatera and Brodský (2014); James (2009).

This text monitors the external communication of authorities. It aims to choose and verify the suitable tool for getting the feedback on the public satisfaction, useful by the municipal offices. This need is continually becoming more topical in the countries of Central and Eastern Europe Maria (2013); Fil'a et al. (2015). Therefore, this paper is concerned with first 
mapping existing ways of determining satisfaction with the quality of services provided to citizens/clients by government agencies at the level of municipalities or regions in the Czech Republic. Subsequently, it proposes appropriate methods for facilitating similar surveys by local municipalities and verifies them on a specific survey that was conducted. It also points to the advantages and prospects resulting from regular use of this tool, i.e. the citizen satisfaction survey. It emphasizes the importance of presenting the results of such a survey in an appropriate way to ensure mutual communication and increase citizen involvement. In conclusion, the authors propose prospects for further investigation.

\section{Formulation of the problems}

The need to investigate the customer's position as well as their satisfaction and loyalty increases as competition increases. Satisfaction and loyalty are often influenced by the expectations and subsequently perceived quality of the given services Morgeson (2013), but there is not always an easy way of estimating their mutual influence. For example, it would be possible to assume that there is a direct relationship between satisfaction and loyalty. However, this was not the result of empirical studies on the degree of satisfaction with local governments (Norway). A positive correlation was confirmed only between the government's reputation and loyalty and satisfaction Andreassen (1994). Despite this, it is important to search for a tool that facilitates monitoring citizen satisfaction as well as identifying causes of dissatisfaction and, simultaneously, ways to help remove these causes and begin increasing satisfaction. At the same time, it is necessary to apply the trend of using public resources economically, i.e. to increase satisfaction proportionally to the effect and costs.

One of the methods used was the SERVQUAL or GAP MODEL method, which was described by Parasuraman et al. (1985). The method is based on determining the customer's expectations and comparing them with the actual perception of the services provided. Wisniewski and Donnelly (1996) and James (2011) rate this method positively; they characterize it as an adaptable diagnostics tool for measuring the quality of services by government managers. On the other hand, Orwig et al. (1997) found that the use of the SERVQUAL method was problematic for the public sector on account of its size. Van Ryzin (2006) assesses its difficulty of use in measuring the differences between expectations and reality in a similar way.

Another possibility is to use a means of measurement employing an index of satisfaction that is determined in advance. The Common Assessment Framework (CAF) is one of the platforms which can be used for systematic investigation of client satisfaction. This is a total quality management tool specifically developed for improving quality in the agencies and organizations of the public administration Stainer et al. (2008). The European Common Indicators (ECI) is an initiative that is also devoted to researching satisfaction Jeníček and Foltýn (2010). This initiative directs research on various aspects influencing satisfaction (e.g., the quality of the city environment, civic facilities, the accessibility of transportation, etc.). The mentioned approaches do not verify the satisfaction with the office work quality.

In the Czech Republic, it is currently possible to find municipalities that have conducted satisfaction research among citizens. In this aspect the used tool is the research on indicators of sustainable development at the local level. Its usage aims at, for example, satisfaction with the local community, the accessibility of civic facilities, citizen willingness to engage in decision-making, safety, etc.; it also makes it possible to include local indicators that examine the current problems of the given municipality. Since 2002 this project helps the municipalities to perform the "Team initiative for local sustainable development, reg. org." with support of the Ministry of the Environment of the Czech Republic Novák (2010). 
Because of its wide thematic scope, it is not entirely possible to use this tool for a survey of citizen satisfaction with local government agencies. In addition to this support for municipalities, the Healthy Cities of the Czech Republic network is also very effective. Among other things, it is focused on supporting sustainable development at the local level; moreover, it does this with the active engagement of the public (under the name Agenda 21).

In the Czech Republic, more narrowly focused research on citizens' satisfaction with government agencies has also been conducted. Municipalities conduct them on their own or with the help of external agencies. In certain cases, a survey is partially financed by the "Human Resources and Employment" Operational Program - examples are surveys by the government agencies of Velké Meziříčí, Ústí nad Orlicí, etc. A more comprehensive project of this type was realized by the Czech Ministry of the Interior during the end of 2007 and beginning of 2008; twelve municipalities participated from the Olomouc and MoravianSilesian Regions Štainer et al. (2008). This survey was based on the Common Assessment Framework (CAF) as listed by the National Information Center for Supporting Quality (2007). A method was created for this project with the goal of making it possible for the survey to be applied to other municipalities. The project was a source of inspiration for further studies. It was focused on determining citizen satisfaction with the services provided by the regional government offices of the Hradec Králové Region in 2010.

The authors state that assigning tasks was problematic, because it was not possible to use experience and findings from research previously conducted on that subject as a starting point Univ. Hradec Králové, Dept. of Soc. (2010). With regard to the fact that the above mentioned studies showed to be insufficient for needs of the Municipality office of the town Pardubice, the application of classic marketing research was designed for given conditions. This application regards the current situation of authorities, and also the currently necessary quality and clarity of web pages, the way of social networks communication, the option of electronic ordering and further specificities based on current situation and needs of the office.

\section{Methods}

During work on this paper, sources of literature were investigated using an applied method. The analysis of these sources predominantly focused on projects conducted in the EU and, more specifically, research applied to the conditions of the Czech Republic. Specific surveys, which had been concerned with investigating citizen satisfaction with various levels of public administration, were compared by the method of comparative analysis.

As no current methodology that could be used for verification of citizens' satisfaction with the municipality was found, the application of marketing research methodology used by companies was proposed, Kozel (2006). This one provides the sufficient space for use also by the municipality. The authors of the text proposed the research method for specific environment of municipalities and the questionnaire structure. It was based on own previous research made among students. The proposed method was specified in detail by requirements of the secretary of the Municipal office of the town Pardubice.

The questionnaire was divided in 7 section. Two are focused on the work of officers and the office environment, one monitored the way of communication between citizens and the office, and the electronic communication of the office (web pages, Facebook profile). In addition, the satisfaction with opening hours and the transport possibilities to reach the office were evaluated. The last section gathered the identification data of respondents. The character of questions was open, closed, half-open as well as there were series of responses. 
Evaluation of this questionnaire was conducted using quantitative analysis, which illustrates the distribution of opinions within the overall number of answers. This is a statistical expression of the respondents' answers. The judgmental sampling method with the use of quotas was used for sample selection.

In order to verify the collected data validity the comparison with two similar researches, of which the focus was partially similar to the research by authors of the text at least, was performed. The comparison mainly monitored the verification how they were gathered and presented (organisation of data collection, analysis and evaluation). This procedure was verified by a quantitative survey intended to contribute to questionnaire data collection techniques for evaluating citizen satisfaction with selected government agencies of the Statutory City of Pardubice. The data of administrative district of Pardubice, according to the Czech statistical office, were used to define the basic set. Over the course of the survey, 262 respondents completed the questionnaire, which amounts to $0.7 \%$ of the basic sample.

\section{An example of applying and proposing a procedure for a citizen satisfaction survey}

One of the primary goals of this paper is to a concrete survey of citizen/client satisfaction of government agencies and to propose an appropriate procedure for facilitating a similar survey. The project researching citizen satisfaction with the City of Pardubice Municipal Authorities was created for this specific purpose Kantorová (2014). The methodologic approach is continuously applied in the text, according to Kozel (2006) that is usually used for the company practice. The project originated in cooperation with Faculty of Economics and Administration of University of Pardubice and the Municipal Authority in the City of Pardubice. A summary analysis of the situation, pretest, and survey were conducted in the year 2014. For the purposes of this study, satisfaction is defined as a quality perceived by a citizen/client with this quality being evaluated primarily on the basis of emotions Lukášová (2009).

The survey goals:

1. To determine the level of satisfaction with handling requests at individual government offices (professional knowledge and an active approach on the part of agency workers, whether the communication was understandable).

2. To determine the level of satisfaction with available information relevant to individual government offices.

3. To determine the level of satisfaction with opening hours and how accessible the offices are by transportation.

The methodologic approach by Kozel (2006):

1. Reserach start and orientation analysis

2. Research planning

3. Data collection

4. Data processing

5. Results analysis and interpretation.

\subsection{The research start and the summary analysis of the situation}

The first step in research starting consists in definition of issues and in targets determination. In case of application in Pardubice the municipality secretary defined two needs: to get data on citizens' satisfaction with municipality services and the possibility to compare the service provision within particular offices of the municipality (so-called internal benchmarking). 
The survey was also preceded by an analysis of the situation. As part of the preliminary research, it was determined that selected students from the University of Pardubice, aged 2225 , visit government agencies most frequently for the following reasons: submitting tax returns and paying fees for the removal of communal waste. Only roughly $25 \%$ of the 60 questioned had visited the office in the last two years. On the basis of a managed interview with a representative of the Statutory City of Pardubice, it was verified that people visit the office with various frequency at various phases in their lives. From the results of the preliminary research, it is clear that it is not possible to consider all citizens living in the given region as the basic sample for the given survey (see 3.2). The project by the Sociology Department of University in Hradec Králové showed similar results (2010).

\subsection{Research planning}

The importance of plan consists in determination of way how to reach the research targets and how to evaluate the particular steps achievements. Thus the faster progress of the whole research project can be ensured. When applied in Pardubice, the following plan was defined: The first stage shall define the way of data collection, the sample size based on the original set and on project possibilities (for example the interviewers' capacity). The second stage proposes and defines the questionnaire and provides training for interviewers. The third stage included the data collection during 2 weeks. The last stage processed, evaluated and presented data to representatives of the municipality office. The whole plan duration was defined for 3 months and the resolvers team members' responsibilities for each stage were defined. The plan fulfilment was continuously monitored. No serious deadline breach occurred.

\section{Defining the basic sample}

Defining the basic sample and creating a sample while mapping service quality is accompanied by a number of complications. When there is a diversity of agendas, it is impossible to establish a basic sample using a simple method. Certain government services are used by nearly all residents of the district and others only by a limited constituency Ryšavý (2009). The goal of the survey thus conceived was to determine the satisfaction of visitors to the Pardubice Municipal Authority's government agencies; therefore, it is possible to consider the basic sample to be all citizens that visited any of the six city agencies in the last 2 years, i.e. those having relatively recent experience. As the city agencies do not record the number of visitors, it was necessary to determine the basic sample on the basis of other available data.

By Dec. 31, 2012, there were 107,948 residents over 15 years old registered in the district of Pardubice; of these, 52,484 were men and 55,464 were women ČSÚ (2013). In addition to the previously mentioned summary analysis of the situation, it was possible for the paper's authors to use the results of the HK project when defining the basic sample. From the sample of 534 respondents, $43 \%$ had been in contact with regional government agencies in the past five years. Preliminary research demonstrated that there had been $25 \%$ active experience with the office in the past two years (see 3.1.). On the basis of the previously listed data, it is possible to estimate that not more than $43 \%$ of the residents of the district of Pardubice older than 15 yrs. comprise the basic sample for the given survey. This includes 46,418 citizens with a gender distribution of roughly $50 \%$.

\section{Determining research sample}

Over the course of the survey, 262 respondents completed the questionnaire, which amounts to $0.7 \%$ of the basic sample. In order to determine the structure of the sample, it is possible to proceed in a number of ways. If the group has known key traits, it is possible to use them for 
quota sampling of the sample and to continue to proceed either on the basis of probability sampling or judgmental sampling. Another possibility is to leave out the step of quota sampling. The law concerning protection of personal data does not allow the systematic creation of a database of citizens visiting government offices with information about their age, gender, or education. Because of this, it is not possible to precisely establish quotas for assembling a sample of respondents in this way. Neither is it possible to proceed from statistical data of the demographic structure of the region. Despite the given limitations, it was possible to establish two quotas for this survey - the rough division of gender at $50 \%$ and division on the basis of an estimation of how frequently individual offices are visited. The survey was conducted such that the number of respondents from each government office corresponded roughly to its rate of visitation. The proposed size of research sample was 250 270 respondents which is approximately $0,7 \%$ of the basic set.

\subsection{Data collection method}

In case of offices it is possible to choose the qualitative research - using the specialised interviewers who perform the deep interviews with limited number of respondents, and the quantitative research. Whereas it can be performed by personal, phone, written or electronic interviewing. The method chosen for this survey was quantitative data collection in the form of a personal questionnaire. Over the course of 14 days, previously trained students from the Faculty of Economics and Administration of University of Pardubice spoke with citizens on site at six agencies and personally questioned them about heir satisfaction. A test of the validity of the acquired data was included as part of the questionnaire. In a number of cases, the visitors were approached while already waiting, the goal being to subsequently finish the questionnaire on their exit. This method proved to be entirely unfeasible (certain respondents were unwilling to complete the questionnaire after taking care of their business). It is recommended that visitors should be approached only as they are leaving.

\subsection{Analysis and interpretation of results}

It is suitable to use the computer technology for data processing. The use of Google documents can be the effective for the transfer of questionnaires in electronic form. This shall ensure their summary organisation and possibility to transfer them in Excel program. Thus collected data can be further classified, treated using basic statistical methods and prepared for presentation of resulting outputs in form of graphs and tables. The survey that took place at the offices of the Pardubice City Authorities introduced data that it is possible to use for improving services and increasing satisfaction of citizens using these offices Kantorová (2014). Only the respondents' identifying data and certain results able to help other government agencies when making decisions about which areas to submit to a similar survey have been selected for this paper on account of the survey's extensive results. At the same time, the published results can help with a general comparison of data acquired from surveying in other municipalities. In case of interest in other results (i.e benchmarking), it is possible to contact the paper's authors.

The data acquired from the questionnaire was processed in the spreadsheet program MS Excel, similarly to the HK project (see 3.1.). The answers were checked for completeness and basic descriptive statistics were conducted. Regarding the type of data, it was not necessary to resolve any influence on results by conceivable outliers. Absolute and relative frequencies for individual questions were calculated only for relevant answers. Irrelevant (incomplete and ambiguous) answers were not included in the calculations. Outputs were achieved using tables, graphs, and contingency tables. 


\section{The sample}

Respondents were approached randomly over the agencies' entire work day. Fig. 1 depicts the respondent sample.

Figure 1: Respondents by Age Distribution

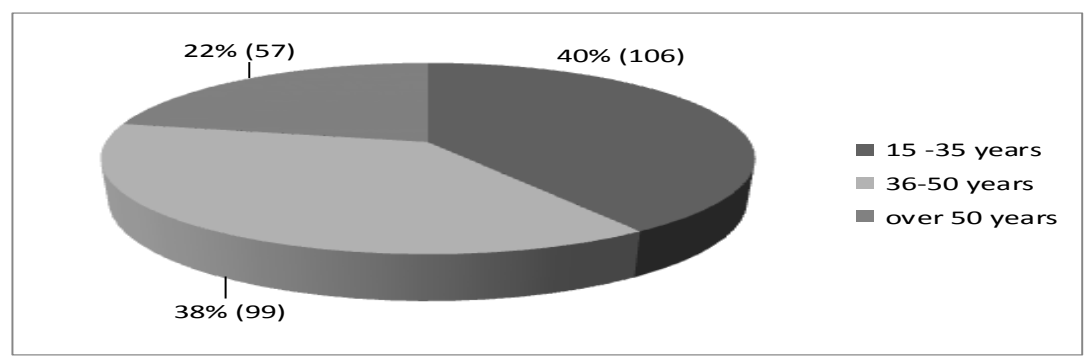

Source: Own research

\section{Survey results}

$79 \%$ of respondents left the agency having resolved their concern. When determining satisfaction with speed of resolution, $40 \%$ were very satisfied, $37 \%$ satisfied, and $23 \%$ somewhat dissatisfied. The questionnaire also evaluated the agency worker's degree of professionalism, how active their approach was, their interest in the client, and whether the communication was understandable. Most of the respondents expressed satisfaction. $7 \%$ of them expressed predominant dissatisfaction with professionalism and how understandable the communication was; $15 \%$ were dissatisfied with the degree of active approach and interest.

The survey was also focused on determining satisfaction with the agencies' accessibility, opening hours, and appointment system. Of the respondents, $23 \%$ used the option of making an appointment in advance, and $73 \%$ were satisfied with the appointment system. Dissatisfaction with the opening hours was expressed by $13 \%$ of those questioned, although $34 \%$ used the extended opening hours. When questioned about which day they would prefer for longer opening hours, the majority did not have a preference. It is interesting to observe the ways that citizens ascertain necessary information. Fig. 2 clearly depicts the prevalence of using the Internet over the option of asking someone, calling a government agency, and other options. Table 1 shows the relationship between age and individual methods of ascertaining information.

Figure 2: Ascertaining Necessary Information

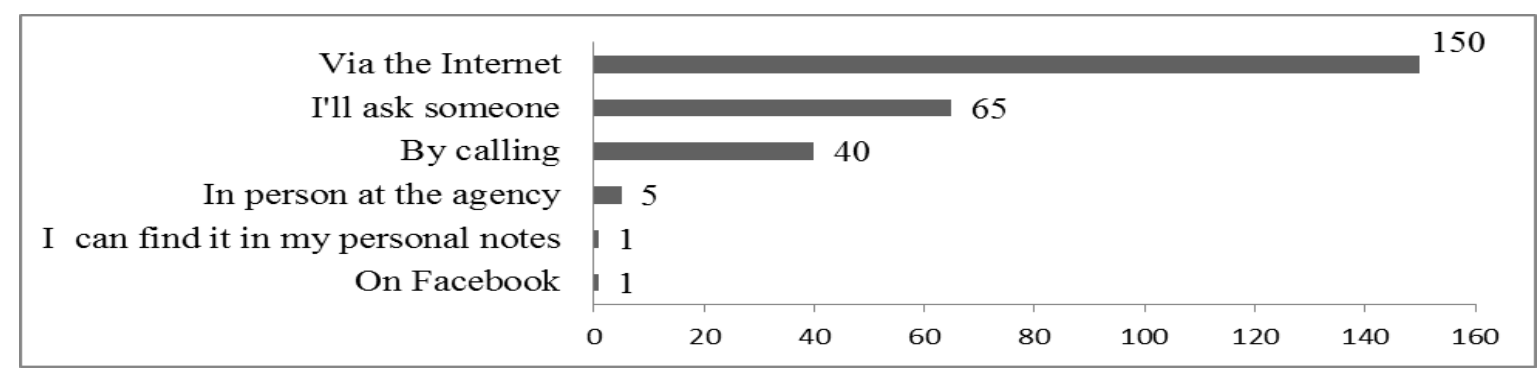

Source: Own research 
Table 1: The Distribution of Individual Modes of Communication for Ascertaining Primary Information Before Visiting a Government Agency by Specific Age Category [\%]

\begin{tabular}{|l|c|c|c|}
\hline & $\mathbf{1 5 - 3 5}$ Years & $\mathbf{3 6 - 5 0}$ Years & Over 50 Years \\
\hline Via the Internet & 68 & 56 & 48 \\
\hline By calling & 9 & 19 & 26 \\
\hline I'll ask someone & 23 & 25 & 26 \\
\hline Total & 100 & 100 & 100 \\
\hline
\end{tabular}

Source: Own research

Regarding websites, respondents were satisfied or somewhat satisfied in $82 \%$ of the cases. Satisfaction with the clarity of these websites was stated by $74 \%$ of those questioned. The city's official Facebook page was visited by $18 \%$ of the respondents.

A comparison of the functions that had been monitored and corresponded to individual city government agencies was included in the survey (see Tables 2 and 3). Because the reason for the respondent visiting the agency was ascertained, it is possible to observe the degree of satisfaction with the specific agencies' individual departments in detail.

Table 2: Satisfaction with the Approach of Govt. Agency Workers According to Agency Function [\%]

\begin{tabular}{|l|c|c|c|c|c|}
\hline Function/Answer & $\begin{array}{c}\text { Very } \\
\text { Satisfied }\end{array}$ & $\begin{array}{c}\text { Somewhat } \\
\text { Satisfied }\end{array}$ & $\begin{array}{c}\text { Somewhat } \\
\text { Dissatisfied }\end{array}$ & $\begin{array}{c}\text { Very } \\
\text { Dissatisfied }\end{array}$ & $\begin{array}{c}\text { Overall } \\
\text { Total }\end{array}$ \\
\hline Trade Licensing Office & 36 & 36 & 25 & 3 & 100 \\
\hline Transportation & 45 & 43 & 10 & 3 & 100 \\
\hline Administrative Records & 53 & 41 & 5 & 0 & 100 \\
\hline Finance Department; Education, Culture & 70 & 22 & 7 & 0 & 100 \\
\hline Building Authority Offices; the Environment & 33 & 51 & 15 & 2 & 100 \\
\hline Social Affairs; Property and Investments & 48 & 26 & 19 & 6 & 100 \\
\hline
\end{tabular}

Source: Own research

When processing the acquired information, it is possible to look for presumed interdependence between the respondents' answers and their identifying traits. In the case of the survey in Pardubice, it seems likely to state a hypothesis regarding a relationship between age and the use of individual modes of communication. It is also possible to further examine the relationship between age and satisfaction with the agency workers' approach, agency facilities, or ease of orientation at the agency offices, etc. This information can help with better understanding the influences contributing to the satisfaction of selected groups of citizens. It is worthwhile to be concerned with such information if an agency is interested in utilizing it. If this is not the case, the result would be a pointless increase in the survey's difficulty and costs. The survey also demonstrated that examining relationships at the level of individual agencies or functions does not, in certain cases, attain a sufficiently relevant value because of the influence of the respondents' dispersion. Observing the relationship between respondents expressing dissatisfaction and the concern that they came to resolve was an example of this. If the goal was to determine relationships at this level of observation, it would be necessary to significantly increase the size of the sample that was investigated. For example, the investigated sample would need to be at least twice as numerous if there were six government agencies. 


\section{The discussion on methodical proposals and resulting further recommendation for research employee}

When comparing research focused on similar attributes, it is good to observe what is evaluated and the values attained. For example, the survey of 12 cities taking part in the $\mathrm{O}$ and MS project found an overall degree of satisfaction between 80 and $97 \%$. The satisfaction determined for 3 specific attributes (competence, helpfulness or activeness, and agency hours) showed fluctuation within a similar range - not only in the HK project survey but also for the study focused on the Statutory City of Pardubice government agencies.

The data listed point solely to the citizens' monumental satisfaction with the agencies. Individual government agencies need to regularly investigate whether citizen satisfaction is increasing. In order to reach an increase in satisfaction, it is necessary to determine what causes perceived satisfaction or dissatisfaction. Open questions that give respondents space to express the reason for satisfaction or dissatisfaction could help agency workers with this Štainer et al. (2008).

Concerning the methods used in the individual research projects, there is an opportunity here to state that citizen satisfaction does not result only from personal contact at government agencies. On the basis of the $\mathrm{O}$ and MS project, it was determined that contact with the agencies occurs most frequently in the form of personal visits and less frequently by contact via telephone, mail (including email), and the use of websites Štainer et al. (2008). However, this trend is changing with increasing information literacy and the prospects for resolving concerns connected with government agencies by electronic means. The HK project recorded that $46.5 \%$ of respondents visited the region's government offices Univ. Hradec Králové, Dept. of Soc. (2010). The project that took place in Pardubice 4 years later recorded a rate of $58 \%$. In relation to this trend, it will be necessary to include even more questions aimed at electronic forms of contact in the satisfaction survey. It will also be necessary to use a combined method of data collection so that a survey can also include citizens who do not visit the agencies in person, but have been in contact with them in a different way.

It is interesting to examine the question of processing answers resulting from the number of possible variants. The HK project, in the same way as the Pardubice survey, used an even number of answers where the respondents had to lean towards either satisfaction or dissatisfaction. Štainer et al. (2008) stated that, when trying to understand the reasons that lead people to satisfaction or dissatisfaction, it is good to divide the respondent sample into satisfied, dissatisfied, and neutral as equally as possible. Paradoxically, respondents' questions are often divided into two groups - those that evaluated the observed traits positively (a value of 1 or 2) and those that chose numbers 3 through 5. From this, it is clear that the middle (undecided) group was artificially moved into the less satisfied spectrum. However, this does not mean that there is no support for whether it is appropriate to consider the possibility of a neutral answer, i.e."I cannot tell."

It is also necessary to point out the common trend of citizens' increasing unwillingness to react to questionnaires and to try as much as possible to slow down this trend. This is necessary because it is important for local governments to conduct surveys repeatedly, among other reasons. Another reason is the fact that the group of those who refused to answer could decrease the objectivity of the research.

A way of approaching respondents and expressing the importance of their opinion for the further development of the situation in the city can contribute to lower negative reaction to 
survey participation. Practically, this can also be helped by reducing the length of the questionnaire, paying attention to what has influence on respondents' willingness to cooperate. Determining causes for unwillingness to answer should also be part of the survey. The most frequent reason in the Pardubice satisfaction survey was time limitation, as it was in the case of Cassia (2008). It can be helpful to enable this group to participate in the survey subsequently (e.g. by an electronic questionnaire) and follow the specific characteristics of this group.

One of the satisfaction survey's sub-goals can be to express interest and opinions of citizens. Ebdon and Franklin (2004) point to the fact that it is necessary to make sure, that citizens do not have the feeling that the opinions they gave in the survey are not valued and utilized. For this reason, it is recommended that a presentation of the information acquired could be given after each survey. Fil'a et al. (2015) state that only $40 \%$ of Slovak cities publish the results of local surveys. They most frequently publish on the Internet - mainly via their own websites at $86 \%$, in the local press and at city council meetings at $37.74 \%$, and via bulletins or posters. In the case of the City of Pardubice survey, the city council meeting and local press were used for making the information public.

\section{Conclusion}

Municipalities are continually trying to increase the quality of the services they offer and subsequently monitor citizen/client feedback. Currently, a number of methods are used for measuring satisfaction. The research goal is of key importance for a municipality or region when deciding which method to choose to acquire the necessary data. If the goal of the research is to determine satisfaction with the quality of services provided to citizens/clients at agencies of the public authorities, then data for evaluation is predominantly acquired using the method of polling. For this purpose the application of methodical approach was proposed that can be performed at the municipality level (with some modification for regions) in order to verify the satisfaction of citizens/clients with chosen services of the office.

The paper proposes procedures to facilitate similar surveys by local municipalities based on the actual Survey of Client Satisfaction by the Municipal Authorities in the City of Pardubice's Kantorová (2014). For example, it proposes the incorporation of preliminary research, in which it is possible to determine facts that are significant for better defining survey goals and a more precise determination of the sample. Additionally, the paper demonstrates how to make sure that the sample is representative as early as in the survey planning phase, thereby ensuring the quality of the data acquired.

The paper's authors offer practical proposals concerning the procedure for establishing survey goals, the forms of questions (e.g. the number of question variants), the method of data collection, prospects for lowering citizens' unwillingness to participate in the survey taking place. Designing the questionnaire was conceived in a way so that it could be used by other government agencies; it is available from the paper's author upon request. For both this project and the projects that were compared, data processing was conducted using basic descriptive statistics and outputs were produced in the form of tables, graphs, and contingency tables; this is sufficient for the needs of government agencies. Where comparing the survey results of the Pardubice Municipal Authority agencies with the other projects examined was possible, similar results were attained for measuring satisfaction. However, a difference was apparent in the growing trend of using electronic modes of contact with agency workers, which corresponds with the overall tendency towards using computer technology in society, and it confirms that the survey proceeded correctly overall. 
This article results in the proposal of marketing research methodology application. This one was verified in the specific research and found by representatives of the town Pardubice as suitable. The representatives of the town showed their interest to repeat this research in the same way after 4 years. Thus the authors of the text consider the target to be fulfilled. The proposal reflects the needs to verify the satisfaction with office of local self-government.

The result of this paper is an application proposal of the marketing methodical survey. For further research, it is recommended that the same questionnaire could be used for other cities, thereby verifying its feasibility and the proposed method in a different environment. At the same time, this would create a prospect for eventual benchmarking between individual municipalities. It would also be possible to examine survey results on various large samples and, with the help of such examination, find an answer to the question of how large a representative sample needs to be, which could significantly save resources in the future. Currently, the paper pointed to the importance of presenting the acquired results in a form suitable for the public, thereby supporting continuing citizen willingness to provide feedback and thus increasing mutual participation in the local municipality.

\section{References}

[1] ANDREASSEN, T. W., 1994. Satisfaction, Loyalty and Reputation as Indicators of Customer Orientation in the Public Sector. International Journal of Public Sector Management, 7(2), 16-34. ISSN 0951-3558.

[2] CASSIA, F., 2008. Citizen surveys inpakt on decisions in local government. Journal of Services Research, 8(1), 109-122. ISSN 09724702.

[3] ČESKÝ STATISTICKÝ ÚŘAD, 2013. Demografická ročenka správních obvodů obcís rozšírenou puisobností [online]. [cit. 2013-09-18]. Available from: www.czso.cz/csu/2013edicniplan.nsf/kapitola/4030-13-r_2013-08000

[4] EBDON, C. and A. FRANKLIN, 2004. Searching for the role for citizens in the budget proces. Public Budgeting and Finance, 24(1), 32-49. ISSN 1540-5850.

[5] FILA, M., L. SCHWARCZOVÁ and L. MURA, 2015. Citizen satisfaction survey as a tool of citizen relationship management of local governmenta in Slovakia. Serbian Journal of Management [online]. 10(1), 117-129 [cit. 2015-05-07]. ISSN 1452-4864. DOI: $10.5937 / \mathrm{sjm} 10-7147$

[6] FRETER, H., 1989. Informationsgrundlagen für Klein - und Mittelbetriebe. In: M. BRUHN ed. Handsbuch des Marketing. München.

[7] HANNAGAN, T., 1992. Marketing for the non-profit sector. London: Macmillan. ISBN 978-033-3525-821.

[8] HEČKO, Š., P. JANEČKOVÁ, V. MALÁTEK and R. ŘIHÁK, 2013. Vnímání míry pocitu bezpečpečnosti občanů města Karviná. Acta academica karviensia [online]. 13(4), 68-88 [cit. 2015-05-07]. ISSN 1212-415X. Available from: www.slu.cz /opf/cz/informace/acta-academica-karviniensia/casopisy-aak/aak-rocnik-2013/docs-42013/Hecko_Janeckova_Malatek_Rihak.pdf

[9] JAMES, O., 2011. Managing citizens'expectations of public service performance. Evidence from observation and experimentation in local government. Public Administration [online]. 89(4), 1419-1435 [cit. 2015-05-07]. ISSN 0033-3298. DOI: 10.1111/j.1467-9299.2011.01962. x 
[10] JENÍČEK, V. and J. FOLTÝN, 2010, Globální problémy světa: v ekonomických souvislostech. 1. vyd. Praha: C. H. Beck. ISBN 978-80-7400-326-4.

[11] KANTOROVÁ, K. and T. RŮŽIČKA, 2014. Průzkum spokojenosti občanů s úřady města Pardubic: Závěrečná zpráva marketingového šetření. Pardubice: Univerzita Pardubice, Fakulta ekonomicko-správní, Ústav ekonomiky a managementu.

[12] KATEDRA SOCIOLOGIE, 2010. Zjištováni spokojenosti občanů Královéhradeckého kraje se službami poskytovanými Krajským úradem Královéhradeckého kraje: Závěrečná výzkumná zpráva [online]. Hradec Králové: Filozofická fakulta Univerzity Hradec Králové, s. 104. Available from: www.kr-kralovehradecky.cz/assets/krajskyurad/kontakt/urad/spokojenost-s-ku_zaverecna-vyzkumna-zprava.pdf

[13] CICVARIĆ KOSTIĆ, S., M. OKANOVIĆ, M. MILOSAVLJEVIĆ and J. VUKMIROVIĆ, 2013. Antecedents of citizens'satisfaction with local administration in Serbia. Transylvanian Review of Administrative Sciences, 40E, 22-34. ISSN 2247-8310.

[14] KOZEL, R., 2006. Moderní marketingový výzkum: nové trendy, kvantitativní a kvalitativni metody a techniky, průběh a organizace, aplikace $v$ praxi, prrinosy a možnosti. 1. vyd. Praha: Grada. ISBN 80-247-0966-x.

[15] LUKÁŠOVÁ, R., 2009. Měřeni spokojenosti občanů s veřejnými službami jako součást rízení kvality v organizacích veřejného sektoru. 1. vyd. Brno: Masarykova univerzita. ISBN 978-802-1051-126.

[16] MARIA, B. F., 2013. The public servants'perceptions regarding the communication proces within local public administration - a qualitative approach. Annals of the University of Oradea, Economic Science Series [online]. 22(1), 1713-1722 [cit. 2015-0507]. ISSN 1582-5450. Available from: www.researchgate.net/profile/Mark_Neal /publication/256432141_Can_Business_Education_Change_Management_Practices_in_ Non-Western_Societies/links/02e7e522860eae971f000000.pdf\#page=1713

[17] MORGESON, F. V., 2013. Expectations, Disconfirmation, and Citizen Satisfaction with the US Federal Government: Testing and Expanding the Model. Journal of Public Administration Research [online]. 23(2), 289-305 [cit. 2014-11-09]. ISSN 1477-9803. Available from: jpart.oxfordjournals.org/content/early/2012/04/19/jopart.mus012.short

[18] NÁRODNÍ INFORMAČNÍ STŘEDISKO PRO PODPORU JAKOSTI, 2007. Společný hodnotící rámec - CAF [online]. 1. vyd. Praha. ISBN 978-80-02-01901-05. Available from: www.eipa.eu/files/File/CAF/Brochure2006/Czech_2006.pdf

[19] NOVÁK, J. et al., 2010. Indikátory mistni udržitelnosti v ČR. Zkušenosti a praxe TIMUR: (Zrcadlo mistní udržitelnosti). 1. vyd. Praha: Týmová iniciativa pro místní udržitelný rozvoj, p. 39. ISBN 978-80-904490-5-3.

[20] ORWIG, R. A., J. PEARSON and D. COCHRAN, 1997. An empirical investigation into the validity of SERVQUAL in the public sector. Public Administration Quarterly, 21(1), 54-68. ISSN 1467-9299.

[21] PARASURAMAN, A., V. A. ZEITHAM and L. L. A. BERRY, 1985. Conceptual Model of Service Quality and Its Implication for Future Research. Journal of Marketing [online]. 49(Fall), 41-50. Available from: www.jstor.org/stable/1251430?origin=JSTORpdf\&seq=1\#page_scan_tab_contents

[22] POISTER, T. H. and G. STREIB, 1999. Performance Measurement in Municipal Government: Assessing the State of the Practice. Public Administration Review [online]. 
59(4), 325. DOI: 10.2307/3110115. Available from: www.jstor.org/stable/ 3110115? origin $=$ crossref

[23] RYŠAVÝ, D., 2009. Kvalita výzkumů ve správě věcí veřejných: př́klady šetření městských zastupitelů a klientů městských úřadů. Data a výzkum - SDA Info 2009 [online]. 3(2). Praha: Sociologický ústav AV ČR. Available from: dav.soc.cas.cz/uploads/a5b92869043842a24d4a7ea0615982b04177c2e4_DaV09_2_pp17 1_186.pdf

[24] RUMPEL, P., 2011. Komplexní regionálni marketing periferního rurálního regionu Jesenicko. Plzeň: Vyd. a naklad. Aleš Čeněk. ISBN 978-807-3803-209.

[25] ŠATERA, K. and Z. BRODSKÝ, 2014. Řizení zdravotnických organizací: (učební text). Pardubice: Univerzita Pardubice, p. 117. ISBN 978-80-86409-43-6.

[26] ŠILHÁNKOVÁ, V. et al., 2010. Jak sledovat indikátory udržitelného rozvoje na místní úrovni?: Návod pro zpracování př́padových studií. Hradec Králové: Civitas per Populi o. s. ISBN 904671-3-2.

[27] ŠTAINER, M., D. RYŠAVÝ and L. ZMEŠKAL, 2008. Šetření spokojenosti klienti̊ úradů. 1. vyd. Praha: Ministerstvo vnitra ČR. ISBN 978-80-254-9273-0.

[28] VAN RYZIN, G. G., 2006. Testing the Expectancy Disconfirmation Model of Citizen Satisfaction with Local Government. Journal of Public Administration Research [online]. 16(4), 599-611 [cit. 2015-05-16]. ISSN 1053-1858. DOI: 10.1093/jopart/mui058

[29] WISNIEWSKI, M. and M. DONNELLY, 1996. Measuring service quality in the public sector: the potential for SERVQUAL. Total Quality Management [online]. 7(4), 357-365 [cit. 2015-05-14]. ISSN 0954-4127. DOI: 10.1080/09544129650034710 